Rosniawaty, S. · R. Sudirja $\cdot$ H. Afrianto

\title{
Pemanfaatan urin kelinci dan urin sapi sebagai alternatif pupuk organik cairpada pembibitan kakao (Theobroma cacao L.)
}

\section{Utilizing of rabbit and cow urine as organic fertilizer liqiud alternative on cocoa (Theobroma cacao L.) seedling}

Diterima : Januari 2015/Disetujui : Februari 2015/Dipublikasikan : Maret 2015

CDepartment of Crop Science, Padjadjaran University

\begin{abstract}
Seedling is the beginning of plant growth. Good seedling will produce high yields. Fertilization is one of the important things in obtaining good seeds. Utilization of rabbit urine and cow urine is expected to be an alternative fertilizer for cocoa seedling. The experiments wereconducted in April-August 2013 at the experimental Ciparanje Padjadjaran University Faculty of Agriculture, with the order Inceptisol and precipitation type $\mathrm{C}$ according to the classification of Schmidt Ferguson. The treatment used was some concentration of rabbit urine, cow urine and urine combination with inorganic fertilizer. Rabbit urine and cow urine each fermented were usedbefore. The experimental design wasused a randomized block design, there are 15 treatment repeated 3 times. The results were showed that there significant effect of rabbit urine and cow urine that had been fermented for leaf area, root volume and dry weight of cocoa seedlings at the age of 16 MST. The used of cow urine with $25 \%$ concentration did not differ with the use of inorganic fertilizers on cocoa seedling.
\end{abstract}

Keywords: Rabbit urine · Cocoa seedling · cow urine $\cdot$ Liquid organic fertilizer

Sari Pembibitan merupakan awal dari pertumbuhan tanaman. Bibit yang baik akan menghasilkan tanaman yang berproduksi baik pula. Pemupukan merupakan salah satu hal penting dalam menghasilkan bibit yang baik. Peman-

\footnotetext{
Dikomunikasikan oleh Yudithia Maxiselly

Rosniawaty, S. · R. Sudirja · H. Afrianto

1 Program Studi Agroteknologi Fakultas Pertanian Unpad

2 Alumni Program Studi Agroteknologi Fakultas Pertanian

Unpad

Jl. Raya Bandung Sumedang, km-21 Jatinangor

Korespondensi: santi.rosniawaty@unpad.ac.id
}

faatan urin kelinci dan urin sapi diharapkan dapat menjadi pupuk alternatif untuk pembibitan kakao. Percobaan telah di laksanakan pada bulan April-Agustus 2013 di Kebun Percobaan Ciparanje fakultas Pertanian Unpad, dengan ordo Inceptisol dan tipe curah hujan menurut klasifikasi Schmidt Ferguson. Perlakuan yang digunakan adalah beberapa konsentrasi urin kelinci, konsentrasi urin sapi dan kombinasi urin dengan pupuk anorganik. Urin kelinci dan urin sapi difermentasikan terlebih dahulu sebelum digunakan. Rancangan percobaan yang digunakan adalah Rancangan Acak Kelompok, terdapat 15 perlakuan yang di ulang 3 kali. Hasil percobaan menunjukkan bahwa terdapat pengaruh penggunaan urin kelinci dan urin sapi yang telah difermentasi terhadap luas daun, volume akar dan bobot kering bibit kakao pada umur 16 mst. Penggunaan urin sapi dengan konsentrasi $25 \%$ dapat menyamai penggunaan pupuk anorganik pada pembibitan kakao.

Kata kunci : Urin kelinci · Pembibitan kakao • Urin sapi · Pupuk organik cair

\section{Pendahuluan}

Tanaman Kakao merupakan salah satu tanaman perkebunan yang merupakan komoditas strategis Jawa Barat. Komoditas kakao yang dikembangkan di Jawa Barat, pada umumnya di tanam di lahan dengan kelas kesesuaian S2, sehingga produksi dan produktivitas belum tercapai (Siti Purnama, 2015). Produksi kakao pada tahun 2013 di Jawa Barat pada umumnya berikisar antara 200-950 kg/ha (Dinas Perkebunan Jawa Barat, 2015), padahal potensi produktivitas kakao unggul bisa mencapai 2500 $\mathrm{kg} / \mathrm{ha} /$ tahun. Peningkatan produksi kakao 
dapat dilakukan mulai dari pembibitan menggunakan kultivar unggul dan pemeliharaan bibit kakao agar dapat berproduksi sesuai potensi di lapangan.

Salah satu kultivar unggulan yang dilepas berdasarkan SK Mentan No. 1694/Kpts/SR.120/ 12/2008 adalah kultivar Sulawesi 1. Kultivar Sulawesi 1 memiliki potensi produksi 1.800-2500 $\mathrm{kg} / \mathrm{ha} /$ tahun, tahan terhadap penyakit Vascular Streak Dieback (VSD) (Direktorat Perlindungan Perkebunan, 2013)

Kultivar unggul dapat tumbuh dengan baik apabila tindakan pemeliharaan dilakukan dengan benar. Tindakan pemeliharaan yang penting dilakukan adalah pemupukan. Pemupukan perlu dilakukan karena tanah atau media tanam tidak dapat menyediakan hara sesuai dengan kebutuhan bibit kakao. Pembibitan kakao memerlukan media tanam berupa campuran tanah, pupuk kandang dan pasir (2:1:1) dan ditambah dengan pupuk ZA $1 \mathrm{~g} /$ tanaman atau NPK $2 \mathrm{~g}$ /tanaman atau $10 \mathrm{~g}$ urea dilarutkan pada satu liter air (Wahyudi, dkk., 2008) atau menggunakan pupuk $1 \mathrm{~g}$ Urea, $2 \mathrm{~g}$ TSP, $2 \mathrm{~g} \mathrm{KCl}$ dan pupuk daun 0,3\% (Balai Pengembangan Benih Tanaman Perkebunan Provinsi Jawa Barat, 2010).

Penggunaan pupuk anorganik secara terus menerus akan menyebabkan kerusakan fisik pada tanah. Kelangkaan dan tingginya harga pupuk anorganik pun merupakan masalah yang dihadapi dalam pembibitan kakao. Perlu dicari alternatif pupuk yang dapat diperoleh dengan mudah, tidak mengganggu lingkungan dan pengaruhnya baik untuk pertumbuhan bibit kakao.

Alternatif pupuk yang dapat digunakan adalah urin kelinci dan urin sapi. Kelinci dan sapi merupakan hewan peliharaan yang dapat menghasilkan urin setiap harinya. Urin merupakan limbah dari hewan, sehingga apabila tidak dimanfaatkan dapat mencemari lingkungan. Sapi akan lebih banyak menghasilkan urin apabila dibandingkan dengan kelinci. Namun demikian urin kelinci memiliki kelebihan dibandingkan dengan urin sapi. Hasil penelitian Rinekso dkk (2011) urin sapi asal Jatibarang yang telah difermentasi selama 15 hari mengadung C organik 4,49 \%, N 0,7 \%, P 0,16\%, $\mathrm{K} 0,62 \%$ serta $\mathrm{C} / \mathrm{N}$ 6,41. Berdasarkan hasil penelitian Badan Penelitian Ternak (Balitnak) tahun 2005 dikutip Setyanto, dkk (2014), kotoran urine kelinci memiliki kandungan unsur $\mathrm{N}, \mathrm{P}, \mathrm{K}$ yang lebihtinggi $(2,72 \%, 1,1 \%$, dan 0,5\%) dibandingkan dengan kotoran dan urine ternak lainnya seperti kuda, kerbau, sapi, domba, babi dan ayam.

Beberapa penelitian menunjukan adanya pengaruh yang baik dari penggunaan urin kelinci dan urin sapi. Hasil penelitian $\mathrm{C}$ de Oliveira, dkk (2009) aplikasi urin sapi 1,25\% ke daun dan $1 \%$ ke tanah direkomendasikan untuk tanaman lettuce (Lactuca sativa).Hasil Penelitian Nugraheni dan Paiman (2010) pada tanaman tomat bahwa konsentrasi urin kelinci 3000 ppm dapat meningkatkan pertumbuhan vegetatif tanaman yaitu berat segar tanaman, berat kering tanaman, berat kering daun dan berat kering batang, tetapi tidak berpengaruh pada pertumbuhan generatif tanaman.

Penelitian penggunaan urin kelinci dan urin sapi yang telah difermentasi pada pembibitan tanaman perkebunan masih jarang dilakukan. Oleh karena itu perlu dilakukan penelitian aplikasi urin kelinci dan urin sapi yang telah difermentasi pada pembibitan kakao.

\section{Bahan dan Metode}

Percobaan dilaksanakan di Kebun Percobaan Fakultas Pertanian Unpad, dengan ketinggian tempat $750 \mathrm{~m} \mathrm{dpl}$, tipe curah hujan $\mathrm{C}$ menurut klasifikasi Schmidt Ferguson (1951) dan ordo tanah Inceptisol. Percobaan dilaksanakan pada Bulan April sampai Agustus 2013.

Benih kakao kultivar Sulawesi 1 (dari Puslitkoka Jember) di tanam pada polibeg berukuran 25 × $30 \mathrm{~cm}$ setelah disemaikan pada karung goni terlebih dahulu. Media tanam pada polibeg adalah campuran tanah dengan pupuk kandang ayam (2:1). Urin sapi dan urin kelinci di fermentasikan menggunakan EM4 selama 3 minggu di tempat yang tidak terkena cahaya matahari. Penggunaan urin kelinci $25 \%$ dilakukan dengan cara melarutkan $250 \mathrm{ml}$ urin ke dalam $750 \mathrm{ml}$ air, begitu pula dengan perlakuan lainnya. Pupuk anorganik yang digunakan berupa urea, SP-36 dan KCl. Pupuk daun yang digunakan banyak tersedia di toko pertanian mempuyai kandungan N-total 11\%, $\mathrm{P}_{2} \mathrm{O}_{5} 8 \%$ dan $\mathrm{K}_{2} \mathrm{O} 6 \%$. Pemberian urin sapi,urin kelinci, pupuk daun dan pupuk anorganik dilakukan setiap dua minggu. Dosis urin sapi dan urin kelinci yang diberikan adalah $22 \mathrm{ml}$ (2 mst), $35 \mathrm{ml}$ (4 mst), $52 \mathrm{ml}$ (6 mst), $61 \mathrm{ml}$ (8 mst), $88 \mathrm{ml}$ (10 dan $12 \mathrm{mst}) 110 \mathrm{ml}$ (14 dan 16 
mst).Bibit kakao ditempatkan pada bedengan yang dinaungi paranet dengan intensitas cahaya yang masuk $60 \%$.

Rancangan percobaan yang digunakan adalah rancangan acak kelompok dengan 15 perlakuan yang diulang 3 kali. Adapun perlakuan yang diberikan adalah sebagai berikut :

A = Urea $1 \mathrm{~g}+\mathrm{TSP} 2 \mathrm{~g}+\mathrm{KCl} 2 \mathrm{~g}$

$\mathrm{B}=$ pupuk daun $0,3 \%$

C $=$ Urin kelinci $12,5 \%$

D $=$ Urin kelinci 25\%

$\mathrm{E} \quad=$ Urin kelinci 37,5\%

$\mathrm{F}=$ urin kelinci $50 \%$

$\mathrm{G}=$ Urin kelinci $12,5 \%$ +urea $1 \mathrm{~g}+\mathrm{TSP} 2 \mathrm{~g}+\mathrm{KCl} 2 \mathrm{~g}$

$\mathrm{H}=$ Urin kelinci $25 \%$ +urea $1 \mathrm{~g}+\mathrm{TSP} 2 \mathrm{~g}+\mathrm{KCl} 2 \mathrm{~g}$

$\mathrm{I}=$ Urin kelinci 37,5\%+urea 1g+TSP $2 \mathrm{~g}+\mathrm{KCl} 2 \mathrm{~g}$

$\mathrm{J} \quad=$ Urin kelinci 50\%+urea $1 \mathrm{~g}+\mathrm{TSP} 2 \mathrm{~g}+\mathrm{KCl} 2 \mathrm{~g}$

$\mathrm{K}$ = pupuk daun $0,3 \%$ +urea $1 \mathrm{~g}+\mathrm{TSP} 2 \mathrm{~g}+\mathrm{KCl} 2 \mathrm{~g}$

$\mathrm{L} \quad=$ Urin sapi $25 \%$

$\mathrm{M}=$ Urin sapi $50 \%$

$\mathrm{N}=$ Urin sapi $25 \%$ +urea $1 \mathrm{~g}+\mathrm{TSP} 2 \mathrm{~g}+\mathrm{KCl} 2 \mathrm{~g}$

$\mathrm{O}=$ Urin sapi $50 \%$ +urea $1 \mathrm{~g}+\mathrm{TSP} 2 \mathrm{~g}+\mathrm{KCl} 2 \mathrm{~g}$

Analisis statistik untuk mengetahui pengaruh perlakuan dengan menggunakan uji $\mathrm{F}$, apabila signifikan, dilanjiutkan dengan uji Scott Knott pada taraf kepercayaan 95\%.

\section{Hasil dan Pembahasan}

Selama percobaan curah hujan semakin berkurang mulai dari 279,5 mm (April), $190 \mathrm{~mm}$ (Mei), $154 \mathrm{~mm}$ (Juni), $149 \mathrm{~mm}$ (Juli) dan $10 \mathrm{~mm}$ (Agustus), sedangkan suhu dan kelembaban berkisar antara $22,9-23,8{ }^{\circ} \mathrm{C}$ dan $85-93 \%$.Kisaran curah hujan, suhu dan kelembaban, masih optimum untuk pertumbuhan bibit kakao. Menurut Pusat Penelitian Kopi dan Kakao (1997) Curah hujan $1500 \mathrm{~mm}$ sampai dengan $2500 \mathrm{~mm}$ per tahun, suhu maksimum $30-32{ }^{\circ} \mathrm{C}$ dan suhu minimum $18-21^{\circ} \mathrm{C}$.

Hasil analisis media tanam menunjukkan bahwa media mempunyai tekstur liat berdebu, C organik tinggi $(3,66 \%), \mathrm{N}$ total tinggi $(0,725 \%)$ $\mathrm{P}_{2} \mathrm{O}_{5}$ total sangat tinggi $(161,01 \mathrm{mg} / 100 \mathrm{~g})$, KTK rendah $\left(12,85 \mathrm{cmol}^{\mathrm{kg}} \mathrm{kg}^{-1}\right)$ dan $\mathrm{K}_{2} \mathrm{O}$ sangat rendah 3,29 mg/100g. Media tanam tersebut masih memerlukan tambahan hara melalui pemupukan.

Hasil analisis di laboratorium Kesuburan Tanah dan Nutrisi Tanaman Faperta Unpad, urin kelinci dan urin sapi yang telah difermentasi tercantum pada Tabel 1. Hasil analisis urin menunjukkan bahwa urin sapi mempunyai $\mathrm{C}$ organik dan $\mathrm{K}_{2} \mathrm{O}$ yang lebih tinggi daripada urin kelinci, sehingga diharapkan dapat menyediakan hara $\mathrm{K}$ untuk bibit kakao.

Tabel 1. Perbandingan Hasil Analisis Urin Sapi, dan Urin Kelinci yang Telah Difermentasikan.

\begin{tabular}{lll}
\hline \hline Jenis Analisis & Urin Kelinci & Urin Sapi \\
\hline $\mathrm{pH}$ & 9,14 & 8,74 \\
$\mathrm{C}$-organik (\%) & 0,62 & 0,74 \\
N-total (\%) & 2,11 & 1,79 \\
$\mathrm{P}_{2} \mathrm{O}_{5}(\%)$ & 1,1 & 0,005 \\
$\mathrm{~K}_{2} \mathrm{O}(\%)$ & 0,5 & 1,68 \\
\hline \hline
\end{tabular}

Tinggi Tanaman. Berdasarkan hasil analisis statistik, tidak terdapat pengaruh nyata pemberian urin kelinci dan urin sapi terhadap tinggi tanaman bibit kakao. Apabila di lihat pada Gambar 1, tinggi bibit kakao mengalami peningkatan setiap umur pengamatan. Perlakuan G (urin kelinci 12,5 \% + urea $1 \mathrm{~g}+$ TSP $2 \mathrm{~g}$ $+\mathrm{KCl} 2 \mathrm{~g}$ ) memiliki peningkatan tinggi tanaman dengan baik. Pada umur 16 mst tinggi tanaman pada perlakuan G mencapai 29,08 cm. Penggunaan perlakuan $G$ dapat menjadi alternatif pengganti pupuk daun yang tersedia di pasaran.

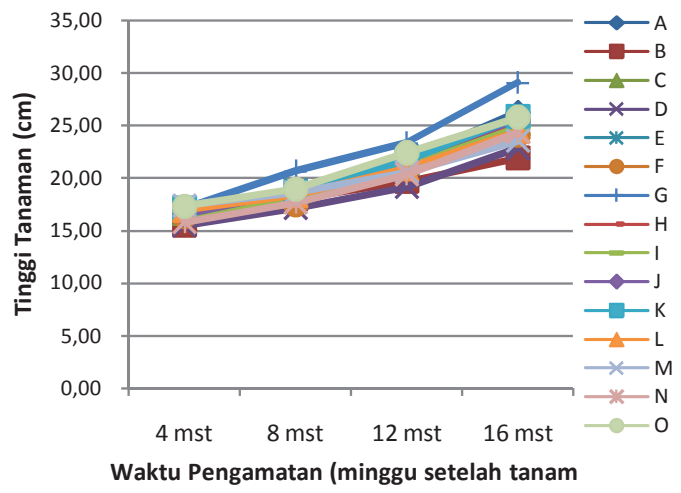

Gambar 1. Aplikasi Urin Kelinci dan Urin Sapi yang Telah Difermentasi pada Tinggi Bibit Kakao Umur 4-16 MST.

Jumlah Daun. Hasil analisis statistik menunjukan tidak terdapat pengaruh nyata dari semua perlakuan terhadap jumlah daun bibit kakao dari setiap umur pengamatan. Hal ini dapat disebabkan pengaruh genetik tanaman lebih dominan apabila dibandingkan dengan pengaruh lingkungan. Terlihat pada Gambar 2, 
semua perlakuan mengalami peningkatan jumlah daun yang sama.

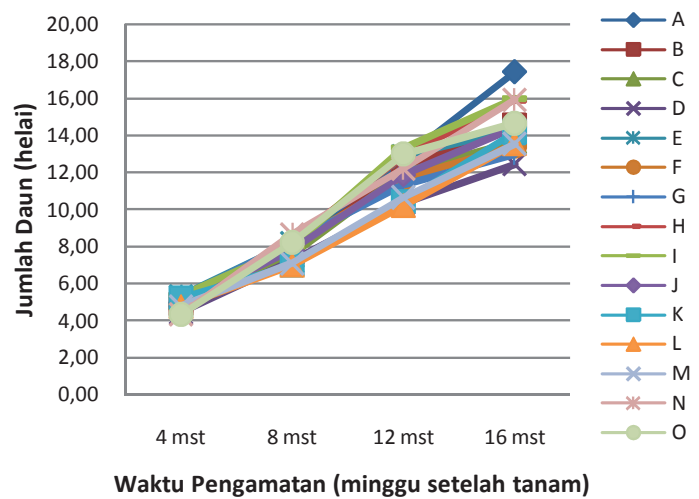

Gambar 2. Aplikasi Urin Kelinci dan Urin Sapi yang Telah Difermentasi pada Tinggi Bibit Kakao Umur 4 -16 MST.

Luas Daun, Volume Akar dan Bobot Kering Bibit. Hasil analisis statistik menunjukan terdapat pengaruh urin sapi dan urin kelinci terhadap luas daun, volume akar dan bobot kering bibit kakao pada umur 16 mst (Tabel 1). Luas daun tertinggi dipengaruhi oleh penggunaan urin sapi $25 \%$ (perlakuan L) yang tidak berbeda dengan penggunaan urin kelinci ditambah pupuk anorganik (perlakuan G) dan penggunaan pupuk daun 0,3\% (perlakuan B). Hal ini memperlihatkan penggunaan urin sapi dapat menjadi alternatif pupuk daun pada pembibitan kakao. Urin sapi memiliki kandungan $\mathrm{pH}$ yang lebih rendah apabila dibandingkan dengan urin kelici, $\mathrm{pH}$ yang terlalu tinggi tidak baik untuk pertumbuhan bibit kakao. Kemasaman urin kelinci yang tinggi menyebabkan kation mangan menyerap anion fosfat sehingga tidak tersedia untuk tanaman (Poerwowidodo, 1993). Unsur P merupakan bahan sumber energy (ATP) untuk fotosintesis. Apabila ATP sedikit maka fotosintesis berjalan lambat danfotosintat yang dihasilkan sedikit sehingga tidak dapat digunakan untuk pertumbuhan daun. Demikian pula pada variebel volume akar, perlakuan urin sapi $25 \%$ (perlakuan L) memiliki volume akar yang lebih tinggi dibandingkan dengan perlakuan lainnya, tetapi sama dengan perlakuan (A,D,E,F,G). Penggunaan pupuk cair mampu menyamai penggunaan pupuk anorganik dalam pembentukan akar. Terdapat kecenderungan penggunaan urin kelinci kurang dari 25\% masih memerlukan tambahan pupuk anorganik.
Bobot kering bibit, yang diberi urin sapi 25 $\%$ (perlakuan L), urin kelinci 12,5\% + urea $1 \mathrm{~g}+$ TSP $2 \mathrm{~g}+\mathrm{KCl} 2 \mathrm{~g}$ (perlakuan G) dan penggunaan pupuk anorganik (perlakuan A) memiliki bobot kering tertinggi dibandingkan dengan perla-kuan lainnya.

Tabel 2. Aplikasi Urin Kelinci dan Urin Sapi yang Telah Difermentasi pada Luas Daun, Volume Akar dan Bobot Kering Bibit Kakao Umur 16 MST.

\begin{tabular}{ccccccc}
\hline \hline Perlakuan & $\begin{array}{c}\text { Luas Daun } \\
\left(\mathbf{c m}^{2}\right)\end{array}$ & $\begin{array}{c}\text { Volume } \\
\text { Akar }(\mathbf{m l})\end{array}$ & \multicolumn{2}{c}{$\begin{array}{c}\text { Bobot Kering } \\
\text { Bibit }(\mathbf{g})\end{array}$} \\
\hline A & 3317.77 & b & 26 & a & 38.73 & a \\
B & 4151.39 & a & 20 & b & 26.25 & b \\
C & 2110.02 & b & 18 & b & 22.68 & b \\
D & 2124.43 & b & 27 & a & 21.5 & b \\
E & 3333.15 & b & 31 & a & 29.66 & b \\
F & 2109.55 & b & 27 & a & 26.7 & b \\
G & 5238.13 & a & 37 & a & 38.91 & a \\
H & 2059.37 & b & 18 & b & 27.97 & b \\
I & 2395.95 & b & 23 & b & 25.38 & b \\
J & 2571.96 & b & 17 & b & 25.33 & b \\
K & 2538.00 & b & 21 & b & 26.85 & b \\
L & 3967.50 & a & 27 & a & 36.63 & a \\
M & 2446.13 & b & 16 & b & 21.84 & b \\
N & 2926.86 & b & 20 & b & 23.75 & b \\
O & 2840.59 & b & 16 & b & 26.36 & b \\
\hline \hline
\end{tabular}

Keterangan: Angka yang diikuti huruf yang sama pada kolom yang sama, tidak berbeda nyata menurut uji ScottKnot taraf kepercayaan 95\%.

Hal ini dapat disebabkan C organik pada urin kelinci lebih sedikit dibandingkan dengan urin sapi, sehingga penggunaan urin kelinci memerlukan pupuk anorganik.Dengan bantuan jasad renik yang ada didalam tanah maka bahan organik akan berubah menjadi humus. Humus ini merupakan perekat yang baik bagi butir-butir tanah saat membentuk gumpalan tanah. Akibatnya, susunan tanah akan menjadi lebih baik dan lebih tahan terhadap gaya-gaya perusak dari luar seperti hanyutan air (erosi). Pemberian bahan organik menyebabkan terjadinya perbaikan struktur tanah, pada tanah berpasir menyebabkan daya ikat tanah meningkat, sedangkan pada tanah berlempung daya ikat air menjadi tinggi, daya ikat tanah terhadap unsur hara meningkat, serta drainase dan tata udara tanah dapat diperbaiki. Tata udara tanah yang baik dengan kandungan air cukup akan menyebabkan suhu tanah lebih stabil serta aliran air dan udara tanah lebih baik. Campbel, dkk (2003) mengemukakan bahwa humus dapat membentuk tanah gembur serta berpori agar aerasi akar terpenuhi.

Kandungan $\mathrm{K}$ yang tinggi pada urin sapi juga mampu menambah ukuran dan volume sel 
di dalam bibit kakao, Fungsi unsur K sebagai kofaktor dalam sintesis protein, keseimbangan air dan pergerakan stomata. Stomata merupakan pintu keluar masuk $\mathrm{CO}_{2}$ sebagai bahan fotosintesis. Apabila stomata mampu mema-sukan $\mathrm{CO}_{2}$ dalam jumlah banyak, fotosintat yang dihasilkan akan banyak dan digunakan untuk pertumbuhan organ tanaman yang diekspresikan berupa bobot kering tanaman.

\section{Kesimpulan dan Saran}

Kesimpulan. Terdapat pengaruh penggunaan urin kelinci dan urin sapi yang telah difermentasi terhadap luas daun, volume akar dan bobot kering bibit kakao pada umur 16 mst.

Penggunaan urin sapi dengan konsentrasi $25 \%$ dapat menyamai penggunaan pupuk anorganik pada pembibitan kakao.

Saran. Penggunaan urin sapi yang telah difermentasi dengan konsentrasi $25 \%$ dapat menjadi alternatif pupuk cair pada pembibitan kakao.

\section{Daftar Pustaka}

Balai Pengembangan Benih Tanaman Perkebunan Provinsi Jawa Barat. 2010. Pedoman Teknis Pembenihan Komoditas Perkebunan. Hlm 60 .

Campbel, N.A., J.B Reece dan LG. Mitchell. 2003. Biologi. Terjemahan Jilid 2. Erlangga.

C de Oliveira, N.L., M. Puiatti,R. Henrique S Santos, P. R. Cecon and P. H. R.Rodrigues. 2009. Soil and leaf fertilization of lettuce crop with cow urine. Abstract. Hortic. Bras. vol.27 no.4 Brasília Oct./Dec. 2009. http://www.scielo.br/scielo.php Diakses tanggal 21 Februari 2015

Dinas Perkebunan Jawa Barat. 2015. Luas dan Produksi Tanaman Perkebunan Provinsi Jawa Barat Tahun 2013, Komoditi Kakao. http:/ / disbun.jabarprov.go.id/index.php/ Diakses 21 Februari 2015.
Direktorat Perlindungan Perkebunan. 2013. Klon Kakao Tahan Organisme Pengganggu Tumbuhan (OPT). http:/ / ditjenbun. pertanian.go.id/perlindungan/berita-146klon-kakao-tahan-organisme-pengganggutumbuhan-opt.html. Diakses 10 Maret 2015

Nugraheni, E.D. dan Paiman. 2010. Pengaruh konsentrasi dan frekuensi pemberian pupuk urin kelinci terhadap pertumbuhan dan hasil tomat (Lycopersicum esculentum Mill).

http://upy.ac.id/agroteknologi/files/PEN GARUH $\% 20 K O N S E N T R A S I \% 20 D A N \% 20$ FREKUENSI\%20PEMBERIAN\%20PUPUK \%20URIN\%20KELINCI\%20TERHADAP\%2 0PERTUMBUHAN\%20DAN\%20HASIL \% 2 OTOMAT.pdf. Diakses 21 Februari 2015.

Poerwowidodo. 1993. Telaah Kesuburan Tanah. Angkasa Bandung

Pusat Penelitian Kopi dan Kakao.1997. Pedoman Teknis Budidaya Tanaman Kakao. Pusat Penelitian Kopi dan Kakao Jember.

Rinekso K. B., E. Sutrisno, dan S. Sumiyati.2011. Studi pembuatan pupuk organik cair dari fermentasi urine sapi (ferisa) dengan variasi lokasi peternakan yang berbeda.

eprints.undip.ac.id/42243/1/JURNAL.doc x. Diakses tanggal 21 Februari 2015

Schmidt, F.H. and J.H.A. Ferguson. 1951. Rainfall Thypes Based on Wet and Dry Period Ratios for Indonesian With Western Nem Duinee. Djulie. Bogor.

Setyanto, N.W. , L. Riawati dan R. P. Lukodono. 2014. Desain eksperimen taguchiuntuk meningkatkan kualitas pupuk organik berbahan baku kotoran kelinci. JEMIS Vol. 2 No. 2 Tahun 2014. Published online at http://JEMIS.ub.ac.id/Copyright@ 2014JTI UB Publishing. All Rights Reserved

Siti Purnama. 2015. Peta Pengembangan Komoditas Perkebunan di Jawa Barat: Realita dan Harapan. Dinas Perkebunan Propinsi Jawa Barat. http://disbun.jabarprov.go.id/ index.php diakses 21 Februari 2015.

Wahyudi T., T.R. Panggabean dan Pujiyanto. 2008. Kakao (Manajemen Agribisnis dari Hulu hingga Hilir). Penebar Swadaya. 